\title{
Ginger Flavor
}

National Cancer Institute

\section{Source}

National Cancer Institute. Ginger Flavor. NCI Thesaurus. Code C100097.

A characteristic of a medicinal product, specifying that its most predominant agreeable savor detected by the unified sensation of taste and olfactory receptors resembles ginger, the rhizome of the perennial plant Zing iber officinale. 